\title{
自動化総合健診システムにおける 健診成績の顔形グラフによる表示
}

$\begin{array}{lrllll}\text { 稲田 } & \text { 紘 }^{1)} \text {, 藤原 } & \text { 誠 }^{2)} \text {, 吉川 } & \text { 博通 }{ }^{3)}, \text { 武田 } & \text { 裕 }^{4)} \text {, } \\ \text { 井上 } & \text { 通敏 }{ }^{4)} \text {, 福島 } & \text { 正勝 }{ }^{5)} \text {, 吉田 } & \text { 途男 }{ }^{5)} \text {, 阿部 } & \text { 裕 }^{6}\end{array}$

はじめに

自動化総合健診システム (Automated Mul-tiphasic Health Testing and Services, AMHTS) において，医師は，面接時に受診者に対して，多 項目にわたる健診成績を提示し，健康状態につい て説明しなければならない。その際，種々の検査 の集団の正常値や受診者の個人正常值との比較か ら, 受診者の状態を理解させることが必要となる が，この場合従来のように，健診成績を数值で提 示するだけでは十分とはいえない。

そこで，各種の検査データや，著者らが設定し た生物学的年齢, 個人正常值, 多変量個人正常值 のようなスクリーニング指標 ${ }^{1}$ の経年変化など を，受診者が視覚的に一目でとらえやすくするた め,これらをコンピュータを用いて, Chernoff の 顔や星座グラフなどにより表示することを計画 し，著者らが進めているコンピュータによる AMHTSの医師の業務支援2の一環にせんとし た。

本研究は，その第一歩として，顔形グラフを用 い，多項目にわたる検査データをパーソナルコン ピュータで表示することを試みたものである。

Presentation of Examination Data of AMHTS Examinees by Facegraph

1) 国立循環器病センター研究所

2) 大阪回生病院

3）住友生命総合健診システム

4）大阪大学医学部附属病院医療情報部

5) 国立大阪病院

6) 大阪労災病院

\section{対象および表示検査項目}

対象として, 住友生命総合健診システムを 5 年 以上, 継続して受診している受診者を選び，その データを表示しようとした。

表示しょうとする検査項目としては，まずスク リーニング指標の設定に用いた項目と同じで, 個 体の特徵を総合的に把握するのに適していると考 えられる 19 項目を選択した。すなわち, 体重, 聴 力 $(4000 \mathrm{~Hz})$, 肺機能 1 秒率, 収縮期血圧, 拡張 期血圧, PSP 15 分值, 血清中の総蛋白, アルブミ ン, 尿素窒素, 総コレステロール, アルカリフォ スファターゼ, 尿酸, GOT および LDH, 空腹時 血糖, $50 \mathrm{~g}$ ブドウ糖負荷 1 時間後血糖值, 赤血球 数, ヘマトクリット, 胸部 X 線心胸比である。そ して,さらに,これらの中から 10 数項目を選び, 各デー夕を顔の輪郭, 目, 眉毛, 鼻, 口の大きさ や角度などに対応させるようにした。

上述した項目のうち, 今回は, 身長と体重から 計算した肥満度 (受診者の体重とBroca の変法に 基づき算出した標準体重との比を\%で表わした比 体重)など 15 項目を選択して，それぞれ顔形グラ フの各部位に対応させた。

表 1 に選択した検查項目と省略記号, および顔 形グラフの対応部位を示す。

\section{顔形グラフの描写方法}

顔形グラフの描写方法としては, Chernoff によ る方法 ${ }^{3)}$ があるが, 本研究では, 受診者の各検査 項目の值の変化が, 直接, それぞれに対応する顔 の各部位の変化として描写されるように, Chernoff の方法をそのまま用いないで, 著書らの考案 
日本総合健診医学会誌

表 1 表示する検查項目と頋形グラフの対成部位

\begin{tabular}{|c|c|c|c|c|}
\hline No. & 検＼cjkstart查＼cjkstart項＼cjkstart目 & 顔形グラフの部位 & 表示可能範囲 & 位 \\
\hline 1 & 肥満度（OI） & 顔の上下比 & $80-160$ & $\%$ \\
\hline 2 & コレステロール (Chol) & 上顔の曲率 & $130-260$ & $\mathrm{mg} d \mathrm{~d}$ \\
\hline 3 & 赤血球数（RBC） & 下顔の曲率 & $380-600$ & $x 10^{4}, \mathrm{~mm}^{3}$ \\
\hline 4 & 尿酸（UA） & 鼻の長さ & $1.5-12.0$ & $\mathrm{mg} / \mathrm{dl}$ \\
\hline 5 & 肺機能 1 秒率 (FEV) & 口の位置 & $50-140$ & $\%$ \\
\hline 6 & 空腹時血糖（FBS） & 口の曲率 & $50-180$ & $\mathrm{mg} d \mathrm{dl}$ \\
\hline 7 & 心胸郭比（CTR） & ロの幅 & $25-60$ & $\%$ \\
\hline 8 & 尿素窒素（BUN） & 目の位置 & $5-80$ & $\mathrm{mg} / \mathrm{dl}$ \\
\hline 9 & GO T (GOT) & 目の間隔 & $5-100$ & U \\
\hline 10 & 収縮期血圧（SBP） & 目の傾き & $90-200$ & $\mathrm{mmHg}$ \\
\hline 11 & 総蛋白質（TP） & 目の曲率 & $6.0-9.0$ & g. dl \\
\hline 12 & L D H (LDH) & 目の幅 & $150-600$ & U \\
\hline 13 & アルカリフォスファターゼ（Alp） & 眉の位置 & $2-20$ & $\mathrm{KAU}$ \\
\hline 14 & P S P 15分值 (PSP) & 眉の傾き & $15-50$ & $\%$ \\
\hline 15 & 拡張期血圧（DBP） & 眉の長さ & $45-110$ & $\mathrm{mmHg}$ \\
\hline
\end{tabular}

した方法によった。著者らの方法を図 1 と図 2 に 示すが, 図 1 は顔の輪郭についての, また図 2 は 眉, 目, 鼻, 口の描写方法を表わしている。

顔の輪郭は, 上顔と下顔に分けて描かれるが, まず最初に任意の位置に顔全体の中心点である点 $\mathrm{O}$ を定める。つぎにこれを原点として，(0,65) の点を上顔の中心に, $(0,-5)$ の点を下顔の中心に 選ぶ。

ついで，上顔と下顔を表わす円を描くが，それ ぞれの半径 UFR, DFR は次の通りである。

$$
\begin{aligned}
& \mathrm{UFR}=190-\mathrm{OI} \\
& \mathrm{DFR}=10+\mathrm{OI}
\end{aligned}
$$

ここで $\mathrm{OI}$ は肥満度 (比体重) であり，身長を $\mathrm{H}$, 体重を W とするとき，次式で表わされる。

$$
\begin{aligned}
& \mathrm{OI}=\mathrm{W} / \mathrm{Wox} 100 \\
& \mathrm{Wo}=(\mathrm{H}-100) \times 0.9
\end{aligned}
$$

これより, 肥満度が大であるほど UFR は小さく, DFR は大きくなる。すなわち, 下半分が大きい顔 として描かれる。このように, 肥満度は顔の上下 比を定める指標となる。

なお, 上顔, 下顔を表わす二つの円の交点 （XCROSS，YCROSS）は次式で表わされる。

$$
\begin{gathered}
\mathrm{YCROSS}=\left\{\left(\mathrm{UFR}^{2}-\mathrm{DFR}^{2}\right)-\left(\mathrm{UYO}^{2}-\right.\right. \\
\left.\left.\mathrm{DYO}^{2}\right)\right\} /\left\{-2\left(\mathrm{UYO}^{2} \mathrm{DYO}\right)\right\} \\
\mathrm{XCROSS}=\mathrm{SQRT}^{\mathrm{D}}\left\{\mathrm{UFR}^{2}-(\mathrm{YCROSS}-\right. \\
\left.\mathrm{UYO})^{2}\right\}
\end{gathered}
$$

ただし，UYO と DYO は，Y 軸方向に測った顔の 中心 $\mathrm{O}$ と, 上顔の中心および下顔の中心との距離 
自動化総合健診システムにおける健診成績の顔形グラフによる表示

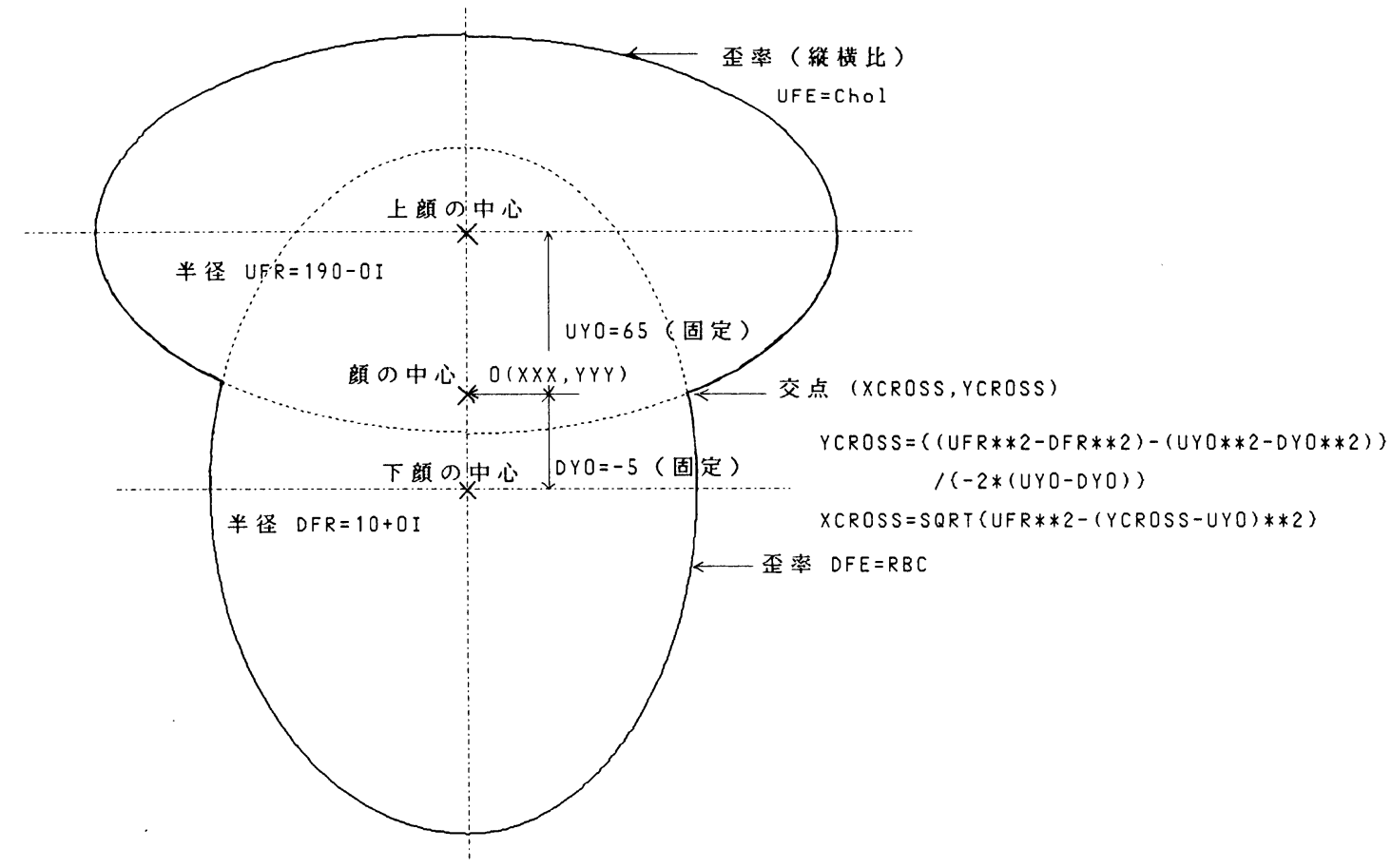

図 1 顔形グラフの描写方法（その1）- 颜の輪郭の描写

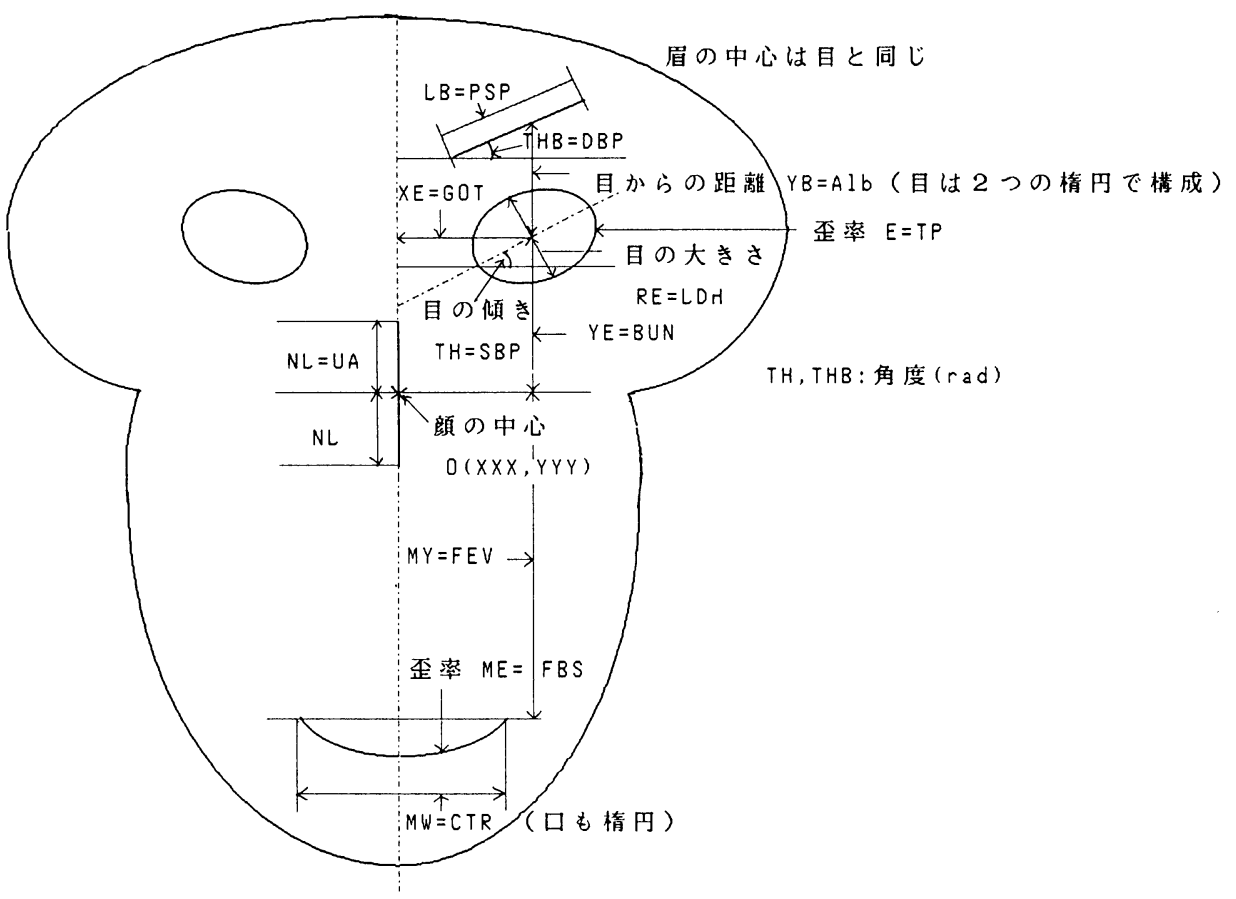

図 2 硠形グラフの描写方法(その 2 ) - 顔の各部位の描写 
である。

こうして作成された上顔と下顔は, 適当な歪率 （縦横比）により楕円に変えられるが，この場合， 上顔の歪率 UFEは血清総コレステロール值 (Chol) によって，また下顔の歪率 DFE は赤血球 数 (RBC) により決定される。そして, 上顔, 下 顔の歪率を示す Chol と RBC の值が大きいほど, それぞれの形を表わす楕円は円形に近づくことに なる。

つぎに目, 鼻, 口, 眉の描き方について記す(図 2 参照)。

まず鼻であるが，これは長さのみで，その指標 には血清尿酸值 (UA) があてられ, 顔の中心であ る原点から，Y 軸の上下にUA の值に相当する長 さNLの線分を引けばよい。

口は楕円の一部によって示されるが，その元の 円の直径は胸部 X 線心胸比 (CTR) の值 MW で 表わされ，空腹時血糖值（FBS）に相当する $\mathrm{ME}$ なる歪率に応じた楕円に変換される。したがって, CTR が大きいほど口幅が広く, FBS が大である ほど曲がった形の口として表わされることにな る。

目の描き方は，まず目の中心点 $(\mathrm{XE}, \mathrm{YE})$ を定 める。ここでXE，YEには，それぞれ血清中の GOT (GOT), 尿素窒素 (BUN) の值が充当され る。目の中心が決まると,つぎに血清 $\mathrm{LDH}(\mathrm{LDH})$ の值に相当する大きさ RE の円が描かれる。そし て, 血清総蛋白值 (TP) の大きさに従う歪率 $\mathrm{E} に$ よる楕円に変えられる。この際, 目を表わす楕円 の長径は，Y 軸に対して TH なる傾きを持つが, この角度 TH (rad) は, 収縮期血圧值 (SBP) の 大きさによるものとする。この結果, SBP が大き くなるほど目がつり上がることになる。

眉毛は，まず目の中心から YBだけ Y 軸に沿っ て上った点 $(\mathrm{XE}, \mathrm{YE}+\mathrm{YB})$ を定め, その点が中 点となる長さ LB の線分を引くことにより描かれ る。ただし, YB は血清アルカリフォスファターゼ (Alp) の值に, また LB は PSP 15 分值 (PSP) に よるものとする。この場合, 眉は目と同様, 拡張 期血圧值 (DBP) によって定まる角度 THB (rad) なる傾きを持つ。したがって, DBP が大であるほ ど眉がつり上がって描かれる。
なお，目，眉とも左右対称に描かれることはい うまでもない。

具体的な検査值を代入して顔形グラフを描く 際，極端な異常により，検査值が非常に大きいか， 小さすぎる值をとる場合には, 目や眉が顔から飛 び出したりするなど, 不都合な結果が生じる。そ こで, 各検査值に表 1 に示すような制限をもうけ, これを表示可能範囲とした。さらに各検查值に正 常範囲を設定したが (表 2), その範囲は通常の正 常値よりも狭い範囲とした。この理由は, AMHTS の受診者の大半が健常者であることか ら, 受診者に注意を促すため, 異常一歩手前のも のでも異常として表示する方が, 健診データの図 形表示の目的にかなうからである。

以上のような方法により, 幾つかの検查值が異 常を示す受診者の顔形グラフを描き, 正常者との 比較から, 異常状態がうまく表現されているかど うかということを検討した。また, 同一の受診者 の時系列データを表示し, その変化の表現度につ いても検討を試みた。

顔形グラフの下の画面には, 各検査データを示 す数値が, その単位と各検查項目の省略記号（表 1参照)とともに表示されるようになっている。こ こで, 各検査項目が顔形グラフのどの部分に相当 するのかがわかるように，それぞれの部位をも示 すようにした(図 3 参照)。さらに, 検査データが 表 2 に示す正常範囲をはずれる場合には, そのデ ー夕を示す数值を赤色で表わした。

\section{システムの概要}

パーソナルコンピュータとして, 日本電気(株) 製 PC 9801 VX 4 システム（内部記憶容量 640 KB）を使用し，これにシャープ (株) 製のカラー CRT ディスプレイ装置 CU-14 A 3 を付随させ た。そして, フロッピーディスクにより, ホスト コンピュータからパーソナルコンピュータへの受 診者の検査データの授受が可能なようにはからっ た。フロッピーディスクには, 受診者の検査デー 夕の管理のため, ID 情報など関連情報をも格納す るようにした。なお，ディスプレイに表示された 内容をハードコピーとして出力しうるようにする ため，プリンタ PC-PR $201 \mathrm{H}$ を使用した。 
自動化総合健診システムにおける健診成績の顔形グラフによる表示

表 2 各検查項目について設定した正常範囲

\begin{tabular}{|c|c|c|c|c|}
\hline No. & 查 & 目 & 正 常範 囲 & 単 位 \\
\hline 1 & 肥満度（OI） & & $95-105$ & $\%$ \\
\hline 2 & コレステロール（Ch & & $140-220$ & $\mathrm{mg}, \mathrm{dl}$ \\
\hline 3 & 赤血球数（RBC） & $\begin{array}{l}\text { （男性） } \\
\text { (女性） }\end{array}$ & $\begin{array}{l}390-550 \\
350-500\end{array}$ & $\mathrm{x} 10^{4}, \mathrm{~mm}^{3}$ \\
\hline 4 & 尿酸（UA） & & $2.5-8.0$ & $\mathrm{mg} / \mathrm{dl}$ \\
\hline 5 & 肺機能 1 秒率 (FEV) & & $80-120$ & $\%$ \\
\hline 6 & 空腹時血糖 (FBS) & & $60-110$ & $\mathrm{mg} / \mathrm{dl}$ \\
\hline 7 & 心胸郭比（CTR） & & 50 以下 & $\%$ \\
\hline 8 & 尿素窒素（BUN） & & $8-22$ & $\mathrm{mg} / \mathrm{dl}$ \\
\hline 9 & GOT (GOT) & & $5-40$ & $\mathrm{U}$ \\
\hline 10 & 収縮期血圧（SBP） & & $100-150$ & $\mathrm{mmHg}$ \\
\hline 11 & 総蛋白質（TP） & & $6.5-8.4$ & $\mathrm{~g} / \mathrm{dl}$ \\
\hline 12 & L D H ( LDH $)$ & & $200-450$ & $\mathrm{U}$ \\
\hline 13 & アルカリフォスファ & -ゼ (Alp) & $4-12$ & $\mathrm{KAU}$ \\
\hline 14 & P S P 15分值 (PSP) & & 30 以上 & $\%$ \\
\hline 15 & 拡張期血圧（DBP） & & $60-90$ & $\mathrm{mmHg}$ \\
\hline
\end{tabular}

なお，前述した方法により顔形グラフを描写す るためのプログラムは, BASIC 言語を用いて作 成した。

顔形グラフを描出するにあたり，使用者はまず ディスプレイに表示された，受診者の検査データ と正常者のそれとの比較を行なう、受診者へのア ドバイスッ，同一受診者の経時変化を見る、時系列 データの比較、のいずれれかのモードをカーソル によって選ぶ。ついで, 受診者の ID と検査年月日 を入力した後, カーソルとキーを使って, 順次, 各検査項目の数值を入力してゆけばよい。

なお，ホストコンピュータからフロッピーディ スクによりデータの受渡しをする場合には，受診 者の ID と検查年月日を入力すれば, 各検査デー
夕は自動的に前述した処理式に代入され，顔形グ ラフが描写される。

\section{結 果}

前述したような方法とシステムにより，幾つか の検査值が異常を示す受診者について描いた顔形 グラフと, 同一受診者の経時データについての顔 形グラフの結果を例示する。

まず図 3 は前者の例で，肥満度が $120 \%$, 空腹 時血糖が $160 \mathrm{mg} / \mathrm{dl}$, 収縮期血圧が $160 \mathrm{mmHg}$, 拡張期血圧が $92 \mathrm{mmHg}$ であり，その他の項目は 表 2 に示す正常範囲にある受診者のグラフであ る。またこの例では, 血清総コレステロールは 220 $\mathrm{mg} / \mathrm{dl}$, 血清尿酸は $8.0 \mathrm{mg} / \mathrm{dl}$ とそれぞれ正常 


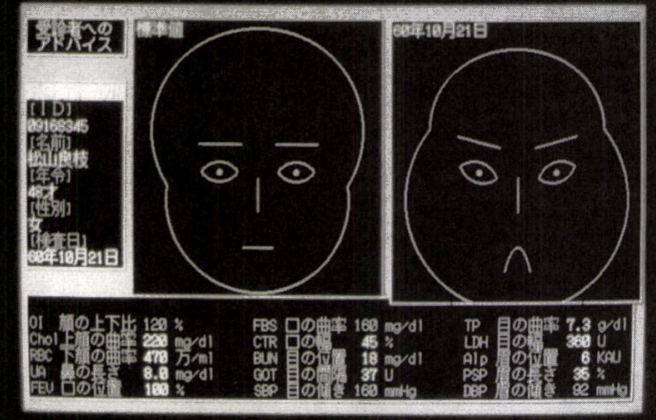

図 3 異常例の顔形グラフ（その 1 )

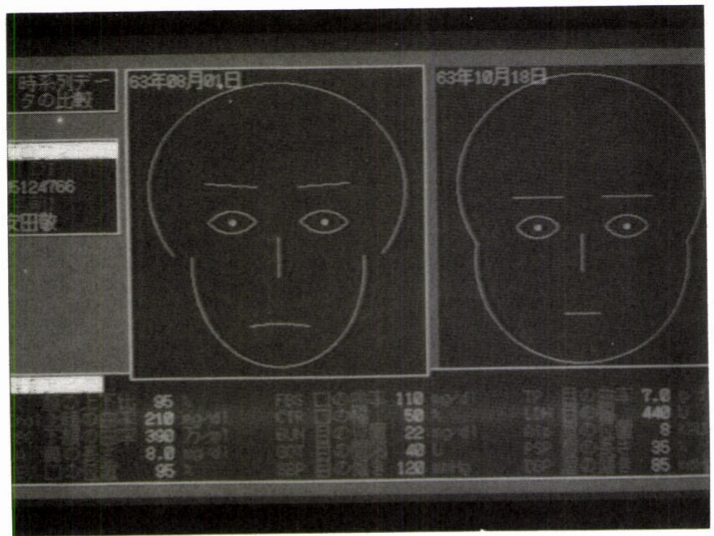

図 5 顔形グラフによる時系列データの比較（その 1)

範囲の上限を示している。その結果，このグラフ を同図の左側に示す正常の場合と比較すると, 顔 の下半面がふくれ，上半面は短縮するとともに， 目と眉がつり上がり,さらに鼻がやや長く，口の 曲率が大きいという顔形が描かれ, 各検査值の異 常を一目で認めることができる。なおグラフの下 面には, 各検查項目の略号と顔形グラフ上の部位, および検査データが表示されている（図 3 では, さらに表 2 の正常範囲をはずれた異常検查項目の 数值が赤色で示されているが, 図 3 はカラー写真 ではないため，認識困難である)。

図 4 は, 血清中の GOT が $80 \mathrm{U}$ を示し, 総蛋白 が $6.3 \mathrm{~g} / \mathrm{dl}, \mathrm{LDH}$ が $470 \mathrm{U}$, アルカリファスファ ターゼが $15 \mathrm{KAU}$ と, 肝機能に関する検査データ が異常な例である。このため, 顔形グラフにおけ

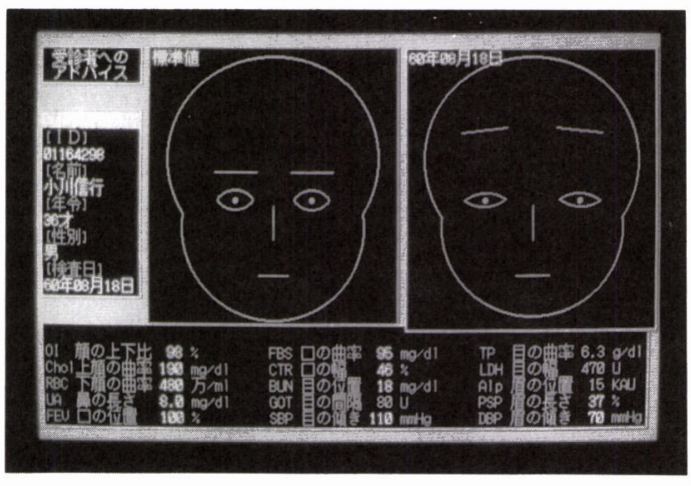

図 4 異常例の顔形グラフ（その 2 )

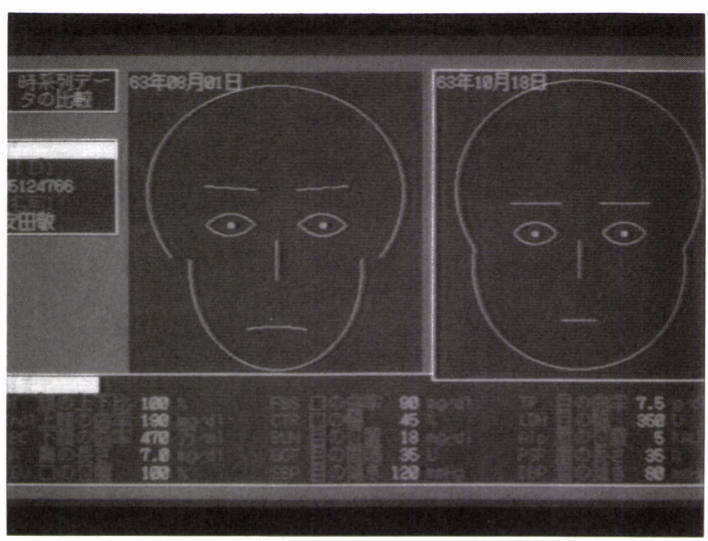

図 6 顔形グラフによる時系列データの比較（その 2)

る目の間隔，目の曲率，目の幅，眉の位置（目と 眉の間隔) といった目に関する部位の形状が普通 ではなく，肝機能が異常であることが容易に理解 される。

次に, 時系列データの表示例を図 5 , 図 6 に示す (図 5 と図 6 の顔形グラフは同じであるが, グラフ の下面の検査データは, 図 5 は左側のグラフの数 值を, 図 6 は右側のグラフのそれを表わしてい る)。

図 5 の左側の顔形は，一応正常ではあるが，顔 形グラフの下面に表示されている検査データから わかるように，表 2 に示す正常範囲の境界値に近 い值を示す検査項目がかなり多い。このため,グ ラフの形状を見ても完全な健康状態にあるとは言 い難いことを窥わしめるものである。 
これに対して，右側は同一受診者の 2 力月後の 顔形グラフを示しており，これより，この受診者 は以前に比べて, より健康な状態にあることが容 易に理解される（このことは, 図 6 に示す 2 カ月 後の検査データからも明らかである)。

以上のように，今回の試みから，顔形グラフに より, 受診者の検査值の集団正常值との差異や, 経時変化を容易に把握することの可能性が示され た。

\section{考 察}

本研究は, AMHTSにおける受診者の多項目健 診成績を Chernoff にならって顔形グラフで表わ し, 受診者が自分の健康状態を視覚的に一目で理 解することを可能にしようとするものである。

図的表示により，多数のデータを視覚的に捉え やすくしようとする方法には, レーダーチャート, 顔形グラフ, 体形グラフ, 星座グラフ, 木形グラ フ, 三角多項式グラフなど種々のものがある。こ のうち, Chernoff による顔形グラフは, 多変量デ ー夕の各変数の值を顔の造作の大きさで表わし, 変数間の相関度と顔の造作間の関連性を対応させ たもので, 多変量データの直観的な把握が可能な 方法として有名である。しかし，このChernoff の 顔形グラフは, これまで, 各国や各都市の経済力 や民度の比較, あるいは企業の財務分析といった ように, 経済を主とするデー夕ないし指標に対す る応用がきわめて多く, 医学的な応用は少数にと どまっている。

医学に対する応用例としては, 近藤らによる長 崎市原爆被爆者定期健診成績の表示がある4)。こ の研究では, 赤血球数, 白血球数, 血色素量, 血 沈, 収縮期血圧, 拡張期血圧の 6 項目のみの検査 值しか使用していないため,貧血とか高血圧など, 2,3 の病的状態しか表わすことができない。した がって, 受診者の健康状態を把握するには不十分 である。

Chernoff の顔形グラフそのものではなく,その 変形である体形グラフを考案した脇本は, これに よって, 学童の体位, 体力診断テスト, 運動能力 テストを表わしている5)。すなわち, 身長, 体重 など体位に関する 4 項目, 反復横とび, 垂直とび
など体力診断テストに関する 7 項目, $50 \mathrm{~m}$ 走, 走 り幅とびなど運動能力テストに関する 5 項目のデ ー夕により, 顔のみならず手, 足など人間の身体 全体を用いて, 図的表示を行っている。この方法 は, 身体計測デー夕や体力に関するデータの表示 に関しては直観的把握が可能であり，優れている といえるが, 本研究のように, 多項目の検査デー 夕を表示し, 受診者の健康状態を視覚的に捉えよ うとする場合には，適切とはいえない。

このように, AMHTSにおける健診データのよ うな多項目の医学データを顔形グラフで表示し, 受診者にそれぞれの健康状態を提示しようとする 試みは見当らず，本研究がはじめてといってもよ い。本研究では, 受診者が単に病気であるかどう かというだけでなく，検査項目ごとに正常範囲を 逸脱したかどうか，あるいは前回の検査值からの 変動はどのくらいか, といったことを顔形グラフ により一目で把握しうるようにするとともに，各 項目の実際の検查值を読みとることが可能になる ことをめざして, Chernoff とは異なる表示方法を 工夫した。そして, 検査データを用いて顔形グラ フを描いた結果，正常状態との差異や，同一受診 者の時系列データの表示に基づく経時変化などを 視覚的に容易に捉えることの可能性が窺われた。

しかしながら,多変量データの表示といっても, 顔形グラフによる方法には, 表示可能な項目数に 制限があるため（本研究における方法では 15 項 目), 総合健診のように, きわめて多数の検查デー タが得られる場合には，そのうちのどれをグラフ 表示すればよいかの判断が困難である。本研究で は，著者らがこれまでに実施した多変量個人正常 值に関する研究の経験に基づき，すでに述べたよ うな個体の特徵を総合的に捉えるのに適している と思われる検査項目を用いたが，受診者の健康状 態を表わすには，これのみでは十分とはいい難い 点が問題である。

顔形グラフによる健診データの表示に関するい ま一つの問題点は, 顔の個々の部位と検査項目と の対応をどのようにするかということである。す なわち, 本研究では, たとえば血清尿酸值を鼻の 長さに対応させているが, この両者の対応にはと くに意味があるわけではないので, 受診者は, 鼻 


\section{日本総合健診医学会誌}

の長さの変化を見て, 直ちに尿酸值の変動である ことを理解しえない。それでも，本研究において は, 図 3 に示すように, 肥満度が大きい場合には, 下ぶくれの顔にしたり，血圧が高值になれば目や 眉がつり上がるなど, 顔の部位と検査項目との対 応にできるだけ工夫するとともに，顔形グラフの 下面にその対応が明示されるようにしている。ま た，各検査項目の数値を示すとともに，健康管理 の立場から設定した正常範囲からはずれた場合に は, 赤色で検査值を示し, 認識が容易になるよう にはからっている。このため, 上述のような問題 点はあるものの, それがとくに支障になっている ことは認められず, 本研究の目的である AMHTS の医師の受診者との面接時における業務支援に有 用であると思われる。

顔形グラフや体形グラフのような表示法ではな いが, 折茂らは, 健診デー夕を図的に表示するに あたって, 前述のような問題点を避けるため, 標 準偏差指数 (SDI) に基づき, 疾患スコアを算定し, これを疾患マップで表示することを試みてい る6)。その方法は, 検体検查を主体とする 53 の検 查項目について SDI を求める。そして, 53 の検査 項目を全身状態, 炎症性疾患など 12 の状態・疾患 に関連の深い項目の組合せに分け，それぞれの状 態・疾患ごとに疾患スコアを求める。スコアの求 め方は, 個々の検査項目の SDI の絶対值により, 一定のポイントを加算し, 検査項目の組合せに基 づく合計点をその状態・疾患のスコアとするもの である。ついで, 全身状態を頭, 血液疾患を動脈 というように，それぞれの状態・疾患を線画で描 いた人体の器官の模式図に対応させ，4段階に分 けた疾患スコアの程度を色表示している。この方 法は, 疾患スコアの求め方に関して若干の問題は あるものの, 健診における多数の検査項目を, そ の組合せにより図的表示を行うことが可能であ り, また, 受診者の状態や疾患の程度をそれぞれ に応じた器官の模式図の色により, 直ちに理解す ることができる。

しかし，こうした方法は，著者らが目的として いるAMHTSの医師の受診者との面接時におけ る業務支援には必ずしも適しているとはいえな い。というのは，折茂らの方法によれば，たとえ
ば, 受診者の血圧値のみが前回の検査値よりも 10 $\mathrm{mmHg}$ 上昇したというような場合, それが疾患ス コアに及ぼす影響は小さく, しかも器官模式図に よる色表示は, スコアがある閾値以上でなければ 次の段階に移行しないから，その表示はまったく 変わらないという場合が少なくない。もちろん, 単に疾病状態かどうかということだけであれば, このような表示法でもよい。けれども AMHTS では,大半の受診者が健常状態か presymptomatic stage にあることを考えると，連続受診者につい ては, 個人正常値という立場から, 時系列的な健 診データを提示し, 検查項目ごとに前回との差異 を把握しうる方法の方が望ましい。

この観点からすれば，著者らの顔形グラフによ る方法の方が優れており, AMHTSにおける医師 の受診者との面接時の業務支援に, より適してい るといえよう。

今後, 顔形グラフのよりよい表現法について検 討するとともに, 多数の項目の検査データを表示 する必要のあるときは, 折茂らによる方法などと の併用をはかることにより, AMHTS における受 診者の健康状態を視覚的に把握する利点がいっそ う増すものと期待されよう。

\section{まとめ}

ANHTS の医師の面接時における業務を支援 するため, その一環として, 受診者が自分の健康 状態を視覚的に一目で理解可能になることをめざ し，つぎのようにして，受診者の多項目にわたる 健診成績を顔形グラフで表示することを試みた。

（1）住友生命総合健診システムを 5 年以上, 継続 受診している受診者について, 個体の特徵を総合 的に把握するのに適していると考えられる肥満度 (比体重), 肺機能 1 秒率, 収縮期血圧, 拡張期血 圧など 15 の検查項目を表示するようにした。

(2) 顔形グラフの描写法として, Chernoff とは異 なる方法を考案し, 各検査デー夕の変動が直接, それぞれに対応する顔の各部位の変化として表示 されるようにした。

(3) 上記の方法に基づき, BASIC 言語を用いてプ ログラムを作成し，パーソナルコンピュータによ り処理して，そのCRTディスプレイ装置に顔形 
グラフを描くとともに，必要時にハードコピーと して出力しうるようにした。

（4）幾つかの検査值が異常を示す受診者の顔形グ ラフを描き，同時に描写した正常者のグラフと比 較したところ，その異常状態を顔形グラフにより 明確に認識可能なことが認められた。

（5）同一の受診者の経時データを顔形グラフで表 示することにより，前回の検査データとの差異を 明瞭に把握しうることが示された。

（6）顔形グラフによる AMHTS の受診者の健診 成績の表示に関しては，表示しうる検査項目数や 検査項目と顔の各部位との対応などに関する問題 点はあるものの, 本研究の目的とする医師の受診 者との面接時における業務支援という観点からは 大きな支障はなく，本研究のような顔形グラフに よる健診成績の表示が有用であることが窥われ た。

\section{文 献}

1）稲田紘, 吉川博通, 平位勉, 武田裕, 井上通敏, 藤 原誠, 阿部裕：連続受診者の Follow-up における 評価に用いる指標の算出, 日本自動化健診学会誌, 10:353-363, 1983.

2) Inada, H., Fujiwara, M., Takeda, H., Inoue, M., Kamada, T., Yoshikawa, H. , Fukushima, M. and Abe, H. : An instruction support system for AMHTS, Automedica, $7: 53$ - 62, 1986.

3) Chernoff, H. : The use of faces to represent points in $\mathrm{k}$-dimensional space graphically, $\mathrm{J}$. Amer. Statis. Assoc., $68: 361-368,1973$.

4）近藤久義, 森弘行：Face一分析を利用した多項目検 查值表示システム, 医療情報学, 4:249-253, 1984 .

5）脇本和昌：チャーノフの顔形グラフの変形の試み： 体形グラフ, 行動計量学会誌, 4 (2):67-73, 1977.

6）折茂淳, 若林正雄: 健診データの図表化出力, 日本 総合健診医学会誌, 4 :323-330, 1985. 